\title{
Understanding Vulnerabilities of Renewable Energy Systems For Building Their Resilience to Climate Change Hazards: Key Concepts And Assessment Approaches
}

\author{
Georgia Sarma(D) and Anastasia Zabaniotou* (D) \\ Department of Chemical Engineering, Aristotle University, Thessaloniki, Greece
}

Received: 25 July 2021 / Received in final form: 17 September 2021 / Accepted: 17 September 2021

\begin{abstract}
The affairs and concerns relating to the energy sector are versatile, spatially differentiated, and dynamic, due to the determining importance of energy in the everyday life of people, national economy, and wellbeing globally. Climate change with extreme and intense weather phenomena, combined with potential biological hazards, affect energy systems, posing a threat to energy systems' resilience and security. understand the interaction of the above factors affecting energy systems, it is necessary to understand the concepts of vulnerability and resilience. This study aims to review factors of vulnerability and resilience of renewable energy systems (RES). Climate change is a significant factor, considered critical for the resilience of renewable energy infrastructure. Conclusions include courses of action and measures that need to be taken, to build resilience. Suggestions are made, for a more sustainable and resilient renewable energy sector, compatible with contemporary technology and eco-friendly behaviors, mandated by climate change.
\end{abstract}

\section{Introduction}

The energy sector in each country is critical to the country's economic development and prosperity. The primary aim of all countries is to ensure the seamless operation of energy systems, with a view to the uninterrupted energy supply [1]. The susceptibility of energy systems to adverse conditions is receiving increasing attention from policy makers, government, industry, and education. Climate change-related hazards have a major impact on energy systems [2]. Climate change has already revealed the increased vulnerability of energy systems [3]. There is a need to integrate in the design, construction, operation and maintenance of planned energy infrastructure issues of resilience [4]. Already in many existing energy systems efforts are taken to adapt them to the everincreasing effects of climate change and reduce their vulnerability.

Energy systems' resilience can be improved through measures and actions targeted at enhancing their capacities and improving risk preparedness and management [4]. Resilience is considered as a key prerequisite for addressing risks arising from climate change. According to research,

\footnotetext{
* e-mail: azampani@auth.gr
}

the effect of a climate change hazard is dependent on the location of the energy system and the flexibility of societies experiencing the adversity [5]. The severity of the adverse event is related to the degree of the impact it has on the eco-social system as a result of its interaction with the energy system [5]. Therefore, it is critical to approach resilience not solely from the mechanical point of view, as the robustness and capacity of a system to return to its original state after any disorder, but to take a systemic approach and all consequences on the eco-social and economic system [6].

The concepts of vulnerability and resilience are particularly significant as they provide frameworks linking biophysical climatic sensitivities with social and economic factors which diminish or amplify the effect of environmental changes [7]. The several resilience strategies combine preparedness for rapid reflexes to stressful conditions while creating long-term and sustainable objectives that enhance socio-economic and environmental operating capability under new climate conditions.

The purpose of this research is to provide a theoretical overview of the concepts of vulnerability and energy systems resilience, to identify vulnerabilities of RES and to make recommendations for enhancing the resilience of RES systems. The research objectives are:

- Identification of the risks to resilience particularly those related to the physical vulnerability of RES. 
- Determination which preventative actions should be implemented to improve RES resilience.

Methodologically, the definitions of the main concepts are presented first, followed by a classification of the hazards impacting energy systems, and indicators of energy vulnerability. This is followed by a review of the vulnerabilities of the renewable energy plants to climate change, geophysical, human, and technological hazards.

\section{Theoretical frameworks, definitions, and classifications}

Natural or anthropogenic man-made hazards can be converted into catastrophes with the influence of environmental conditions and other external variables, resulting in disastrous outcomes, loss of life and infrastructure destruction [8].

Energy system infrastructure is critical to a country, yet they present vulnerability to risks and attacks [3]. Energy systems vulnerability is defined as the degree to which a system is subjected to detrimental events or changes, severe economic, social, environmental, or governmental conditions [9]. is also defined as the level of the system's inflexibility to cope with certain stressful conditions [10]. Many cases of energy systems' vulnerability are local or regional, linked to geographical identification. Each country's energy sector is composed of several segments (electricity, oil, gas, and RES), which are geographically scattered and interconnected through networks and systems [11].

According to International Strategy for Disaster Reduction (ISDR), risks are typically classified into two major categories, natural and anthropogenic or technological [12]. Natural risks are divided into geophysical, meteorological, hydrological, climatic, biological hazards, including toxic substances, insects, and microbes like the on-going Covid-19 virus. Anthropogenic and technological hazards are classified into (a) large industrial or technological accidents and (b) acts of aggression.

The geophysical hazards include earthquakes, floods, landslides, tsunami, avalanches, and meteorological hazards, that can significantly affect energy systems and increase their vulnerability [13]. Earthquakes are defined as territorial movements caused by a disruption of the mechanical energy of rock from natural sources, converting their dynamic energy into kinetics. It is the outcome of a long-term process of dynamic energy accumulation in stressed regions of the lithosphere. They are classified into collapses, volcanic and tectonics [13]. Floods that are the temporary inclination in some area of water caused by excessive rainfall, snow melt are categorized in coastal floods, river floods, flash floods [14]. Fires and wildfires are defined as the rapid combustion processes that requires the presence of a fuel, air oxygen and heat [15]. Landslides indicate a sudden mass movement of residual soil rock or sediment, including any movement caused by sliding, falling, overturning, flowing, and creeping, and the notions of precipitation and collapse are distinct from the concept of landslide $[16,17]$. Volcanic eruptions are described by the International Federation of Red Cross (IFRC) as the activity and all phenomena connected to the rise and release of molten material from the earth's interior onto its surface [18]. Tsunami is a Japanese word, comprised of two ideographs that mean "harbor waves" when combined. Tsunamis are single waves or multiple waves, generated in a volume of water by a thrust imbalance that vertically raises a water column. Earthquakes, landslides, volcanic eruptions and even meteor drops can create tsunamis [19]. Extreme weather phenomena include heavy rainfall, windstorm tornadoes, snowstorms, frost, fog, hail, heat, and drought [20].

Anthropogenic or technological disasters are caused by anthropogenic hazards. Earth's population growth, globalization, and climate change have created global challenges and increased vulnerability of all systems to natural and technological disasters producing also long-term psychological effects and insecurity to individuals [21]. The most serious technological hazards are the heavy industrial accidents and nuclear energy accidents that are can be devastated. Large-scale accidents in nuclear power stations have been caused mainly by human factors and natural stresses. The most recent major nuclear accident happened at Fukushima in Japan after a deadly tsunami [22].

Another industrial hazard is the leakage of toxic substances into the atmosphere which can affect populations and nearby societies and cause deaths or poisoning, local contamination of crops, livestock, and water [23]. Toxic substances are the flammable liquids and solids, oxidants, organic peroxides, corrosive materials, compressed gases, flammable compressed gases, poisons, irritants, inhaled dangerous substances, radioactive constituents, and other dangerous substances. The transport of dangerous substances can also lead to particularly serious accidents [24]. However, often the people involved do not have proper training and knowledge, making for them difficult to determine the flow of events that led to the accident [25].

Acts of aggression are wars and terrorism. A condition of hostility, conflict, or antagonism or a state of usually open and proclaimed armed hostile confrontation between states or nations, is known as war [26], while terrorism is the systematic use of force to create a general climate of fear in a population, with the aim of establishing a comparable political objective [27].

There is also serious chemical, biological and radiological hazards. The chemical threat is caused by any chemical (solid, liquid, gaseous) which, by its action in living organisms, may cause death, temporary inability (inactivation) or permanent damage to the body of humans [28], while the biological threats are living organisms (bacteria and viruses) or biotoxins (biological by-products) that cause diseases in animals and humans. The Covid-19 pandemic is a biological global treat [29]. Radiological agents include all radiological substances and can create radiological hazards differentiated from the nuclear agents by their origin [30]. 


\section{Energy systems vulnerability factors and measurement indicators}

The vulnerability of the energy sector is a complex issue and depends on many factors. These factors are presented below.

\subsection{Dependency on external primary energy supply}

The vulnerability of energy systems is directly related to their dependency on energy sector imports. The ratio of net energy imports to total (primary) energy consumption in a country is used to quantify the extent of the country's dependency. The degree of this dependency varies, according to the energy type, as well as geopolitics; it can be expressed by the Hirschmann-Herfindahl Index (HHI) that is the sum of the squared market shares held by the various suppliers, according to the equation (1):

$$
\mathrm{HHI}=\sum_{i} S_{i}^{2}
$$

where $S_{i}$ is the market share of each supplier in the oil supply of the relevant country [30].

A HHI value between 8.000 and 10.000 indicates a significantly high supply, implying a vulnerability concern. A value of $\mathrm{HHI}<2.000$ signifies a diversified supply, and as a result, lower vulnerability [31]. In general, a value of HHI $>2500$ indicates vulnerability [30]. Countries of the European Union (EU) have high rates of dependency regarding the energy imports [32].

Vulnerability indicators specific to the dependency on oil and natural gas are (a) the oil vulnerability index (OVI) and the (b) natural gas vulnerability index (NGVI) [33]. For the measurement of market risk for oil and natural gas, the primary energy security fuel index (PES) is used. PES is expressed in tons of oil per unit of gross domestic product (GDP) of the country or in $\mathrm{m}^{3}$ of natural gas per unit of GDP [34]. Indicators that capture and quantify the impact of geopolitical concerns are to evaluate and measure the supply risk. Supply risk refers to the risks and hazards of physical disruptions of fuel supply. They are known as 'geopolitical risks' and are categorized into the 'political measurement' indicator and the 'market liquidity' indicator [34]. Two other indicators assess a country's energy mix supply diversification: (a) the diversification of primary energy demand (DPED) and (b) the net energy import dependency (NEID) [34].

\subsection{Energy budget}

Vulnerability may also be associated with the high level of energy import value in GDP. It refers to the quantity and cost of energy imports. The energy bill (EB) balances the trade and GDP. The EB involves numerous elements, indicating that it is dependent on many factors and can consequently be reduced in a variety of ways [35]. EB is expressed by the equation:

$$
\mathrm{EB}=\mathrm{ED} * \mathrm{INT} * \mathrm{AC} * \mathrm{ER}
$$

EB: is the cost of net energy imports (i.e., net import bill (NEB), expressed in euros) in relation to GDP (expressed in euros); (wherefrom $\mathrm{EB}=\mathrm{NEB} / \mathrm{GDP}$ ); $\mathrm{ED}$ : is the rate of energy dependency, i.e. the ratio of net energy imports (or NEI intoe) to primary energy consumption (or PEC in toe); (wherefrom $\mathrm{ED}=\mathrm{NEI} / \mathrm{PEC}$ ); INT: is the energy intensity of GDP, i.e., the ratio of the quantity of primary energy (expressed in toe) to GDP (expressed in euros); (wherefrom INT $=\mathrm{PEC} / \mathrm{GDP}$ ); AC: is the average supply cost, i.e., the weighted average cost of net energy imports bill expressed in $\$$ (or NEB) to net energy imports (NEI), expressed in toe. It is therefore the weighted average cost in dollars per unit of imported toe and accordingly = NEB/NEI; ER: is the average euro to dollar exchange rate (i.e., e rate $/ \$$ rate).

It is evident that the 'cost' of the vulnerability of energy imports is linked to a high quantitative dependence on energy imports, as well as to a high cost per ton of imported quantity. The energy security index (ESI) was recently suggested as a novel index that incorporates the following components: fuel availability, technical development, economic affordability, social accessibility, governance, unexpected threats, and natural environment, [36].

\subsection{Black-out}

One of the most important segments of the energy systems is the electricity sector, and its susceptibility is dependent on the reserve margin, interconnection level with foreign countries, net electricity import rate [30]. For public energy monopoly systems, the 'reserve margin' of a surplus capacity is related to the peak power demand, since one of the main priorities of electricity security is to prevent system's failure. However, this 'margin' is a costly strategy since reserve capacities are not used and the end-user bears the cost referred as the "capacity surplus" logic [30]. On the market level, firms seek not to have an overcapacity that increases risks of energy failure, unless the regulator imposes a public service obligation on all the operators. The concept of 'failure cost' may be defined as the macroeconomic cost of a disruption on the electricity network. This cost is defined as the ratio of non-supplied electricity to electricity demand, expressed by the equation (3), [30]:

$$
\gamma=\alpha f^{2}+b f+c
$$

where $\gamma$ is the failure cost (non-supplied marginal $\mathrm{kWh}$ ) and $a, b$, and $c$ are parameters to be estimated [30].

$\mathrm{EU}$ suggest member states to make connections between their electricity network and neighboring countries' network (cross-border connections), at a level of $10 \%$ of their established network, aiming to reduce the risk of a possible black-out and to reduce vulnerability of the electricity system [30]. Since, electricity cannot be stored, dependence on foreign countries for electricity supply implies a high risk. Therefore, an important indicator of the electric system vulnerability is the "net electricity import rate" that is the percentage of the electricity consumption that is imported. The ratio of investment to turnover certainly offers a good indicator of the level of vulnerability of the electricity [37]. 


\subsection{Price volatility}

Energy vulnerability is linked to the volatility of energy prices. This volatility increases the cost of irreversibility (sunk costs) creating the need to think about "stability" mechanisms and end-user costs paid to preserve some sections of the industrial sector from excessive energy prices fluctuations [30]. In the electricity sector, the price volatility is detrimental for end-user and operators in charge of generation. Transmission, and distribution, are potential factors of vulnerability because transmission and distribution are activities that bring a large share of the profits to electricity companies, [38-40]. There is great uncertainty about the performance of generation and marketing activities faced with new markets opening, due the market share of each operator [30].

Europe is currently tackling the major issue of energy vulnerability of end-industrial users, due to price fluctuations. Electricity price is much more volatile compared to other forms of energy because electricity cannot be stored [41]. To resolve the issue, the following measures are proposed [30], (a) new legal regulated tariffs, (b) reliable contracts, (c) long-term contracts between large industrial end-users and electricity suppliers.

\subsection{Exchange rate}

Energy vulnerability can be linked to variations in currency exchange rates if it is imported. Currency devaluation can make investors' choices vulnerable if they get into debt on the international financial markets [30].

\subsection{Industrial factors}

Takeovers are part of the risks inherent in a marketoriented economy. There is a risk for incumbents in the electricity and gas sectors if the electricity is under the hands of public corporations. This is generally the case for production and marketing companies. In several European countries it is also the case with transmission and distribution subsidiaries [42-44].

\subsection{Technological options}

The technological options and infrastructures and the lack of innovation can increase the energy vulnerability of a country. This leads to the country's dependence on traditional forms of energy (oil, gas) and disables the country to make innovative energy choices. Reducing energy vulnerability entails increasing the countries efforts on $\mathrm{R} \& \mathrm{D}$, and innovation [30].

\subsection{Energy security}

Continuous affordable provision of energy services is a high priority of every nation. Energy security entails three characteristics: (a) robustness of the system (sufficiency of resources, reliability of infrastructure, and stable and affordable prices); (b) sovereignty (protection from potential threats from external agents); (c) resilience [45].

\subsection{Energy transition}

Reducing energy vulnerability and increasing energy sector security entails the use of RES [30]. The energy transition is a path towards shifting the global energy sector away from fossil-based and towards low carbon energy sources. RES can potentially deliver $90 \%$ of the required carbon reductions. A clear vision of a new energy system is based on renewable technologies and complemented by green hydrogen and modern bioenergy. This new system is technically viable and ready for accelerated and widespread adoption [46].

\section{Vulnerability of renewable energy systems (RES) to climate change hazards}

RES such as wind, solar, bioenergy, all depend on the climatic conditions of the area concerned [47]. EUROCORDEX models showed a relatively small dependence of solar and wind energy on climate change, with a slight decrease in annual wind energy in southern Europe, while the north annual production remains relatively stable and unchanged [48]. Climate change increases the solar radiation in the southern Europe and decreases it in the northern countries [49].

Natural climate variability is caused by variations in large-scale atmospheric circulation patterns which strongly modulate the temperature, wind, and irradiation for large parts of Europe. The North Atlantic Oscillation (NAO) is the most important mode of atmospheric variability over the North Atlantic sector in the winter and plays a major role in weather and climate variation over eastern North America, the North Atlantic, and the Eurasian continent [50]. During winter, a positive NAO generally leads to windy strong conditions in northern Europe, while southern Europe enjoys relatively sunny and dry conditions. With a negative NAO, the storm track over the North Atlantic Ocean is located much more to the south, bringing cloudy and windy conditions to the southern part of Europe while northern Europe generally has calm, cool and dry weather [51]. A significant correlation has been found between the NAO and the performance of wind energy. Negative NAO enhances wind speed (10-20\%) and reduces radiation (10-20\%) In the Mediterranean region annual fluctuations of $20 \%$ in the performance of Res in wintertime, have been detected [52].

Climate change affects solar energy. This results from the levels of atmospheric humidity, cloudiness, and characteristics of the clouds that affect atmospheric permeability having an impact on the production of electricity from photovoltaic panels [53]. Hydroelectric power is directly dependent on the water supply and therefore on the water cycle and seasonal variation of water flows. Climate change has a significant impact on the operation of hydroelectric plants, whose severity varies geographically. The melting of ice caused by climate change in many parts of the world has reduced the quantities of water provided and therefore makes it difficult for hydroelectric plants to operate [54]. Liquid biofuels are also vulnerable to climate change, since biomass growth 
Table 1. RES vulnerabilities.

\begin{tabular}{|c|c|c|}
\hline Hazard & System & Vulnerability \\
\hline & Hydroelectric power plant & $\begin{array}{l}\text { Changes in temperature seasonally increases } \\
\text { and decreases water availability }\end{array}$ \\
\hline & Biomass and Bioenergy & $\begin{array}{l}\text { Increased temperatures adversely affect } \\
\text { harvest of crops, either by reducing yields or } \\
\text { leading to destruction }\end{array}$ \\
\hline Temperature rise & Photovoltaic (PV) & $\begin{array}{l}\text { The efficacy of panels is reduced by } 0.5 \% \text { for } \\
\text { every } 1{ }^{\circ} \mathrm{C} \text { increase in temperature }\end{array}$ \\
\hline Fire & All energy systems & $\begin{array}{l}\text { Fires threaten infrastructure and the } \\
\text { unhindered operation of all energy systems }\end{array}$ \\
\hline Landslide & All energy systems located in coastal areas & \\
\hline \multirow[t]{3}{*}{ Sea level rise } & $\begin{array}{l}\text { Natural gas infrastructure (liquefied gas } \\
\text { terminals) }\end{array}$ & $\begin{array}{l}\text { The infrastructures of coastal energy systems } \\
\text { are at risk from flooding. }\end{array}$ \\
\hline & Marine hydrocarbon extraction facilities & \\
\hline & Gas stations of the interconnected system & $\begin{array}{l}\text { Reduced availability of water results in } \\
\text { reduced energy availability of thermal plants } \\
\text { cooled from lakes or rivers }\end{array}$ \\
\hline \multirow[t]{2}{*}{ Drought } & Hydroelectric power plants & $\begin{array}{l}\text { Reduction in water reserves, resulting from a } \\
\text { reduction in rainfall, leading to a reduction } \\
\text { in their productivity. }\end{array}$ \\
\hline & Biomass / Bioenergy & $\begin{array}{l}\text { Change in soil conditions leading to effects } \\
\text { on crops productivity. }\end{array}$ \\
\hline Windstorm, Cyclone, Hurricane & $\begin{array}{l}\text { Electricity transmission and distribution } \\
\text { network }\end{array}$ & $\begin{array}{l}\text { Black-out and power outage risk, as well as } \\
\text { material damage to parts of the electrical } \\
\text { network. }\end{array}$ \\
\hline \multirow[t]{4}{*}{ Hail, Storm, Lightning } & Photovoltaic (PV) & $\begin{array}{l}\text { Exposure to weather adversities, such as } \\
\text { heavy hail, makes PV vulnerable leading to } \\
\text { destruction or trouble. }\end{array}$ \\
\hline & Wind farms & Risk of stress damage \\
\hline & All energy systems close to aquifers & $\begin{array}{l}\text { Risk of destruction of energy system } \\
\text { infrastructure. }\end{array}$ \\
\hline & $\begin{array}{l}\text { Electricity transmission and distribution } \\
\text { network }\end{array}$ & Risk of destruction of coastal infrastructure. \\
\hline \multirow[t]{2}{*}{ Flood } & Hydroelectric power plants & $\begin{array}{l}\text { Flood phenomena lead to water storage } \\
\text { problems due to increased drainage of } \\
\text { aquifers. }\end{array}$ \\
\hline & Biomass / Bioenergy & $\begin{array}{l}\text { Destruction of crops, leading to a reduction } \\
\text { in available raw materials }\end{array}$ \\
\hline \multicolumn{3}{|l|}{ Geophysical vulnerabilities } \\
\hline Earthquake & All energy systems & Buildings damages \\
\hline Tsunami & All energy systems & Buildings damage in coastal areas \\
\hline Volcanic eruption & All energy systems & Buildings damage in volcanic areas \\
\hline
\end{tabular}


Table 2. Anthropogenic and technological risk's scenarios for RES [55].

\begin{tabular}{ll}
\hline Risk & Description \\
\hline Major technical failure & A large technical failure that can result in system shutdown \\
Human error factor & Human errors cause system dysfunction, entirety or partly \\
War & War affects import of raw materials from countries where a war is happening. \\
Strikes & Strikes cause major problems to the functioning of energy systems \\
Dependencies & Disturbances in the national interconnection network create power disorders \\
Terrorist attack & It cuts off the threatened system from its connections \\
Financial crime & A financial motivated criminal organization targeting companies of production, \\
distribution etc. & \\
Sabotage & The saboteur usually has little knowledge of the network and is capable of a \\
Treat from inside & The-dimensional attack \\
\end{tabular}

Table 3. Economic, technical, and geopolitical risks impact on electricity supply [56].

\begin{tabular}{lll}
\hline Hazard & Energy system & Impact \\
\hline
\end{tabular}

\section{Economic risks}

Unexpected increase in energy price

Interruption or reduction of international energy supply.

Disruption of domestic and local energy supplies.

Green Electricity Bioelectricity

Gradual reduction of biofuels stocks

\section{Technical risks}

Uncertainty in the supply of biofuel to a power plant

Engineering problems and equipment failures

\section{Geopolitical risks}

Reforms in environmental legislation affecting energy supply
Green Electricity Bioelectricity

Green Electricity Bioelectricity
The price of the fuel used to generate electricity is likely to change leading to uncertainty as to the cost of production.

Energy cuts have a significant impact on national accounts, and can lead to an increase in inflation, trade and wage imbalances, high unemployment, low consumer safety

Possibility of disrupting domestic energy supply due to local and temporary problems which may be adverse weather events, strikes and/or accidents

Economic pressures create minimization trends in commercial fuel stocks (both in the distribution chain and in the place of use) and storage capacity in production units and transmission systems

Fuel adequacy in a power plant may be unreliable leading to inability to produce. The supply of fuel depends both on its availability and on the reliability of the mode of transport

Requirement of periodic maintenance

Non-compliance with existing laws and regulations on environmental protection against the effects of electricity generation and compliance costs are quite high. This risk depends largely on the fuel and technology used for production. depends on temperature, rainfall, and carbon dioxide levels. The latter affects agriculture, such as crop yields, rural distribution zones, the increases the need of fertilizers and pesticides while makes not suitable some lands suitable for specific crops [47].

The vulnerability of RES can be territorial and systemic. In interconnected systems the vulnerability of certain infrastructure significantly affects the whole energy system. Table 1 shows the types of vulnerabilities of RES systems to various stressors and Table 2 shows the hazards for RES systems related to anthropogenic and technological risks [55].

There is a need to make specific reference to certain risks that make a decisive contribution to the vulnerability of electricity. The benchmarking of risks involved in electricity supply are classified into 4 categories: (a) economics, (b) technical, (c) geopolitical and (d) legal as Table 3 shows [56]. 
Table 4. Characteristics of resilient RES.

\begin{tabular}{|c|c|}
\hline Characteristic & Description \\
\hline Robustness & $\begin{array}{l}\text { Describes the system's strength to withstand internal and external shocks without } \\
\text { suffering from major impairment in major functions }[64,65]\end{array}$ \\
\hline Stability & Expresses the system's stable and uninterrupted operation [63] \\
\hline Flexibility & It is the ability to perform necessary functionsunder a wide variety of conditions [66] \\
\hline Resourcefulness & $\begin{array}{l}\text { It relates to the resources disposal and preparedness of urban planners and decision } \\
\text { makers to appropriately prepare for, respond, and recover from possible disruptions } \\
{[65,67]}\end{array}$ \\
\hline Redundancy & $\begin{array}{l}\text { Refers to the availability of components with similar function in the urban system to } \\
\text { ensure that failure of one component would not cause the whole system to stall }[64,65]\end{array}$ \\
\hline Diversity of energy & $\begin{array}{l}\text { A resilient city should be diverse in terms of energy supply, use patterns, } \\
\text { infrastructure, knowledge, [65] }\end{array}$ \\
\hline Independence & $\begin{array}{l}\text { A resilient system should have a certain degree of self-reliance that equips it with the } \\
\text { ability to maintain a minimum acceptable level of functioning (without external } \\
\text { support) when influenced by disturbance }[4,68]\end{array}$ \\
\hline Interdependence & $\begin{array}{l}\text { It refers to having mechanisms in place that enable a system, as part of an integrated } \\
\text { network, to receive support from other systems in the network [64] }\end{array}$ \\
\hline Adaptability & $\begin{array}{l}\text { It refers to a system's capacity to learn from past disturbances and its flexibility to } \\
\text { adapt to the changing conditions }[64,65]\end{array}$ \\
\hline Self-organization & $\begin{array}{l}\text { It refers to the emergence of macro-scale patterns or properties resulting from } \\
\text { smaller-scale rules [65] }\end{array}$ \\
\hline Creativity & $\begin{array}{l}\text { It refers to the system's capacity to exploit the disturbance as an opportunity to } \\
\text { advance to a higher level. This necessitates utilizing innovation in planning and } \\
\text { management [69] }\end{array}$ \\
\hline Efficiency & $\begin{array}{l}\text { It implies that the ratio of energy and resources supplied by an urban system to the } \\
\text { energy delivered to it as input, is positive [64] }\end{array}$ \\
\hline
\end{tabular}

Besides the above cases of vulnerabilities, there are also some anticipated failures that RES systems can face. All engineered systems, such as energy infrastructures, require periodic maintenance and suffer by occasional equipment failures. Experience, technical knowledge, and skillful personnel is needed to repair and mainly to decrease failure rates, to balance the cost of maintenance, and replacement. These expectations are conditional upon routine conditions [57]. The simultaneous impact of multiple hazards on the vulnerability of RES infrastructure is likely not to have a cumulative but a non-linear impact [58].

\section{Which RES are resilient?}

An energy resilient urban system should be able to ensure availability, accessibility, affordability, and acceptability of energy supply, under varying conditions, capacity to face a disaster, absorb shocks, recover, and adapt rapidly [63].

- They are the key critical infrastructure of modern societies [59].

- They ensure the of sustainability of energy supply [60].
- They need proper and adequate preparation, and management to stand up against different types of disasters [61].

- They are less complex than other critical interdependent and interconnected energy infrastructures [62].

- The characteristics of resilient RES are depicted in Table 4.

An evaluation of the resilience of energy systems to climate change risks requires consideration of climate changes and a framework that includes all the various components of energy systems and their complex interactions. The primary strategies to assess the resilience of RES to climate change are presented in Table 5.

Energy storage capacity expansion, transmission lines to transport renewable power from resource-rich geographic areas to non-rich ones, and the availability of resources that adjust electricity usage patterns are proposed to provide reliable electric service to customers with a renewabledominated resource mix [81]. Another major concern is the maintenance of the grid's resilience, given an increased penetration of renewable resources. In this context, resilience refers to the grid's capacity to withstand and recover rapidly from low-probability, high-impact incidents that are typically natural hazards [82]. 
Table 5. Approaches for assessing the resilience of RES.

- Measuring resilience by considering the type of the extreme event, the time durationof the disturbanceand its impact on performance indicators [70]

- Formulation of resilience as the system's capability to maintain its reliability during

- adverse events [71,72]

- Use the System-of-systems framework that integrates three main models for weather,

- components and the system [73]

- Applying the risk management and investment perspective by using reliability

- assessment frameworks for handling hazardous conditions [74]

- Determination of the system's capacity to fulfil energy security through interactions and the interrelations of the important elements of the system [75,76]

- Classification of disruptive climate-induced events into five categories of minor,

- moderate, serious, major, and extreme impact, depending on the frequency and duration

- of the event as well as the number of consumers being affected [77]

- Proposing a methodology for energy security assessment (defined as minimum vulnerability of

- keyl energy systems) under long-term energy scenarios [78]

- Distinguish between three basic weather conditions: average, severe and extreme [79]

- Consider multiple climate scenarios from local climate models, time periods for energy demands and generation, optimize the energy system and assess it by using indicators [80]

\section{Conclusions}

RES will have a significant part in the energy mix in most of the countries. However, as all energy systems, they are threatened by climate change and anthropogenic hazards. Climate change, terrorism, or disruption of the variable power supply of RES are the main factors creating multiple hazards to their uninterrupted operation.

Building resilient RES is crucial in mitigating climate change particularly when considering the effects on the electrical grid. Proper design and planning for resilience within the framework of a renewable-dominated electric grid is important for reducing physical vulnerability and accelerating the climate change adaptation.

\section{References}

1. Ö. Esen, M. Bayrak, Does more energy consumption support economic growth in net energy-importing countries? J. Econ. Finance Adm. Sci. 22, 75-98 (2017)

2. V.M. Nik, A.T.D. Perera, D. Chen, Towards climate resilient urban energy systems: a review, Natl. Sci. Rev. nwaa134, doi:10.1093/nsr/nwaa134 (2020)

3. A. Gatto, F. Busato, Energy vulnerability around the world: the global energy vulnerability index (GEVI), J. Clean. Prod. 253, 118691 (2020)

4. R. Roggema, A. van den Dobbelsteen, Swarm planning for climate change: an alternative pathway for resilience, Build. Res. Inf. 40, 606-624 (2012)

5. R.A. Eagle et al., High regional climate sensitivity over continental China constrained by glacial-recent changes in temperature and the hydrological cycle, Proc. Natl. Acad. Sci. 110, 8813-8818 (2013)

6. UN. Sustainable, resilient and inclusive societies - the path towards transformation. in Together 2030 written inputs to the UN High-Level Political Forum on Sustainable Development(HLPF) (2018)

7. K. Maki, K. Forssen, M. Raikkonen, Factors of vulnerability and resilience in energy systems. in CIRED Workshop 2016101 (4 .)-101 (4 .) (Institution of Engineering and Technology). doi:10.1049/cp.2016.0701. (2016)

8. D. Petley, Global patterns of loss of life from landslides, Geology 40, 927-930 (2012)

9. A. Gatto, C. Drago, Measuring and modeling energy resilience, Ecol. Econ. 10 (2020)

10. E. Gnansounou, Assessing the energy vulnerability: case of industrialised countries, Energy Policy 36, 3734-3744 (2008)

11. S. Carley, T.P. Evans, M. Graff, D.M. Konisky, A framework for evaluating geographic disparities in energy transition vulnerability, Nat. Energy 3, 621-627 (2018)

12. Global Assessment Report on Disaster Risk Mangement United Nations Human Settlements Programme, 2013

13. K. Sapountzaki, A. Baladinaki, Necessity of and benefits from a multi-risk urban observatory: the case of the Southernmost Town of EU, Ierapetra, Crete. in (2014)

14. E.J. Plate, Flood risk and flood management, J. Hydrol. 267, 2-11 (2002)

15. https://public.emdat.be. https://public.emdat.be/data

16. K. Terzaghi, Mechanism of Landslides, in Application of Geology to Engineering Practice, edited by S. Paige (Geological Society of America, 1950). doi:10.1130/Ber key.1950.83

17. D.J. Varnes, Slope movement: Types and Processes. In Special Report 176: Landslides: Analysis and Control (1978)

18. Volcanic eruptions - IFRC. https://www.ifrc.org/en/whatwe-do/disaster-management/about-disasters/definition-ofhazard/volcanic-eruptions/

19. Tsunamis - IFRC. https://www.ifrc.org/en/what-we-do/ disaster-management/about-disasters/definition-of-hazard/ tsunamis/ 
20. N. Agrawal, Defining Natural Hazards - Large Scale Hazards. in Natural Disasters and Risk Management in Canada, Springer, Netherlands (2018), vol. 49, pp 1-40

21. C.B. Mayhorn, A.C. McLaughlin, Warning the world of extreme events: a global perspective on risk communication for natural and technological disaster, Saf. Sci. 61, 43-50 (2014)

22. Nuclear Power in the European Union - World Nuclear Association. https://www.world-nuclear.org/information-li brary/country-profiles/others/european-union.aspx (2020)

23. D.A. Novelo-Casanova, G. Suárez, Natural and man-made hazards in the Cayman Islands, Nat. Hazards 55, 441-466 (2010)

24. FEMA, Annual Report 1983 (1983)

25. A. Tumanov, Risk assessment of accidents during the transportation of liquid radioactive waste in multimodal transport, IOP Conf. Ser. Earth Environ. Sci. 272, 032078 (2019)

26. Definitions of Hazard Assessment. American Chemical Society https://www.acs.org/content/acs/en/chemical-safe ty/hazard-assessment/tools/definitions.html

27. J.P. Jenkins, Terrorism (2018)

28. Biological Threat | disasterassistance.gov. https://www. disasterassistance.gov/information/disaster-types/biologicalthreat

29. S. Meulenbelt, Assessing chemical, biological, radiological and nuclear threats to the food supply chain 15 (2018)

30. J. Percebois, Energy vulnerability and its management, Int. J. Energy Sect. Manag. 1, 51-62 (2007)

31. R. Golecha, J. Gan, Effects of corn stover year-to-year supply variability and market structure on biomass utilization and cost, Renew. Sustain. Energy Rev. 57, 34-44 (2016)

32. C.V. Roupas, A. Flamos, J. Psarras, Measurement of EU27 oil vulnerability, Int. J. Energy Sect. Manag. 3, 203-218 (2009)

33. C. Roupas, A. Flamos, J. Psarras, Comparative analysis of EU member countries vulnerability in oil and gas, Energy Sources Part B 6, 348-356 (2011)

34. E. Gupta, Assessing the relative geopolitical risk of oil importing countries, in Chapter 13 ( 2007)

35. P. Criqui, J. Percebois, Stratégies énergétiques: cigales et fourmis, Economies et Sociétés série EN 37-51 (1988)

36. A.J. Paravantis, N. Kontoulis, Energy security and renewable energy: a geopolitical perspective, in Renewable Energy - Resources, Challenges and Applications, edited by M. Al Qubeissi, A. El-kharouf, H. Serhad Soyhan, (IntechOpen (2020). doi:10.5772/intechopen.91848

37. Capgemini, Observatoire européen des marchés de l'énergie (2005)

38. O.E. Williamson, Industrial Organization. (Elgar) (1990)

39. B. Tenenbaum, R. Lock, J. Barker, Electricity privatizationStructural, competitive and regulatory options, Energy Policy 20, 1134-60 (1992)

40. D.M. Newbery, Privatization, Reconstructuring, and Regulation of Network Utilities, MIT Press (2000)

41. B. Sevi, Marches a terme et marches derives; les bourses europeennes d'electricite, Universite de Montpellier (CREDEN), (2005)

42. W. Hogan, Electricity market restructuring: reforms of reforms, J. Regul. Econ. 103-131 (2002)

43. D. Helm, Energy, the State, and the Market: British Energy Policy since 1979 Oxford Press (2003)
44. J. Percebois, Ouverture a la concurrence et regulation des industries de reseaux: la cas du gaz et de l'electricite, Econ. Publique 12, 71-98 (2003)

45. A. Cherp et al., Energy and security, in Global Energy Assessment (GEA), edited by T.B. Johansson, N. Nakicenovic, A. Patwardhan, L. Gomez-Echeverri, Cambridge University Press (2012), pp. 325-384

46. World Energy Transitions Outlook: $1.5^{\circ} \mathrm{C}$ Pathway, International Renewable Energy Agency (2021)

47. P. Ravestein, G. van der Schrier, R. Haarsma, R. Scheele, M. van den Broek, Vulnerability of European intermittent renewable energy supply to climate change and climate variability, Renew. Sustain. Energy Rev. 97, 497-508 (2018)

48. I. Tobin et al., Climate change impacts on the power generation potential of a European mid-century wind farms scenario, Environ. Res. Lett. 11, 034013 (2016)

49. S. Jerez et al., The impact of climate change on photovoltaic power generation in Europe, Nat. Commun. 6, 10014 (2015)

50. R.J. Greatbatch, The North Atlantic Oscillation 30 (2000)

51. J.W. Hurrell, Decadal trends in the North Atlantic oscillation: regional temperatures and precipitation, Science 269, 676-679 (1995)

52. E. Anastasiou, K.O. Lorentz, G.J. Stein, P.D. Mitchell, Prehistoric schistosomiasis parasite found in the Middle East, Lancet Infect. Dis. 14, 553-554 (2014)

53. H.W. Cutforth, D. Judiesch, Long-term changes to incoming solar energy on the Canadian Prairie, Agric. For. Meteorol. 145, 167-175 (2007)

54. R. Schaeffer et al., Energy sector vulnerability to climate change: a review, Energy 38, 1-12 (2012)

55. A.J. Holmgren, Using graph models to analyze the vulnerability of electric power networks, Risk Anal. 26, 955-969 (2006)

56. G. Kowalski, S. Vilogorac, Energy security risks and risk mitigation: an overview 7 (2008)

57. A.E. Farrell, H. Zerriffi, H. Dowlatabadi, Energy infrastructure and security, Annu. Rev. Environ. Resour. 29, 421-469 (2004)

58. A.F.P. de Lucena et al., The vulnerability of renewable energy to climate change in Brazil, Energy Policy 37, 879-889 (2009)

59. H.R. Heinimann, K. Hatfield, Infrastructure resilience assessment, management and governance-state and perspectives. In Resilience and risk. (Springer, 2017)

60. G. Mutani, V. Todeschi, Energy resilience, vulnerability and risk in urban spaces, J. Sustain. Dev. Energy Water Environ. Syst. 6, 694-709 (2018)

61. P. Gasser et al., A review on resilience assessment of energy systems, Sustain. Resilient Infrastruct. 1-27 (2019), doi:10.1080/23789689.2019.1610600

62. M. Ouyang, Review on modeling and simulation of interdependent critical infrastructure systems, Reliab. Eng. Syst. Saf. 121, 43-60 (2014)

63. A. Sharifi, Y.A. Yamagata, Conceptual framework for assessment of urban energy resilience, Energy Proc. 75, 2904-2909 (2015)

64. M. Fleischhauer, The role of spatial planning in strengthening urban resilience, in Resilience of Cities to Terrorist and other Threats, edited by H.J. Pasman, I.A. Kirillov, Springer, Netherlands (2008), pp. 273-298 
65. M.E. Krasny, K.G. Tidball, Applying a resilience systems framework to urban environmental education, Environ. Educ. Res. 15, 465-482 (2009)

66. S. Tyler, M. Moench, A framework for urban climate resilience, Clim. Dev. 4, 311-326 (2012)

67. S.L. Cutter et al., A place-based model for understanding community resilience to natural disasters, Glob. Environ. Change 18, 598-606 (2008)

68. T.G. Frazier, C.M. Thompson, R.J. Dezzani, D. Butsick, Spatial and temporal quantification of resilience at the community scale, Appl. Geogr. 42, 95-107 (2013)

69. B. Frommer, Climate change and the resilient society: utopia or realistic option for German regions? Nat Hazards 17 (2013)

70. S. Moslehi, T.A. Reddy, Sustainability of integrated energy systems: A performance-based resilience assessment methodology, Appl. Energy 228, 487-498 (2018)

71. G. Fu et al., Integrated approach to assess the resilience of future electricity infrastructure networks to climate hazards, IEEE Syst. J. 12, 3169-3180 (2018)

72. Y. Zhou, M. Panteli, R. Moreno, P. Mancarella, System-level assessment of reliability and resilience provision from microgrids, Appl. Energy 230, 374-392 (2018)

73. M. Panteli, P. Mancarella, Influence of Extreme Weather and Climate Change on the Resilience of Power Systems: Impact and Possible Mitigation Strategies 30 (2015)
74. M. Keogh, C. Cody, Resilience in Regulated Utilities (2013)

75. M. Chaudry et al., Building a Resilient UK Enegry System (2011)

76. F. Gracceva, P. Zeniewski, A systemic approach to assessing energy security in a low-carbon EU energy system, Appl. Energy 123, 335-348 (2014)

77. A. Kenward, U. Raja, Blackout: extreme weather, climate change and power outages 23 (2014)

78. J. Jewell, A. Cherp, K. Riahi, Energy security under de-carbonization scenarios: An assessment framework and evaluation under different technology and policy choices, Energy Policy 65, 743-760 (2014)

79. D.M. Ward, The effect of weather on grid systems and the reliability of electricity supply, Clim. Change 121, 103-113 (2013)

80. A.T.D. Perera, V.M. Nik, D. Chen, J.-L. Scartezzini, T. Hong, Quantifying the impacts of climate change and extreme climate events on energy systems, Nat. Energy 5, 150-159 (2020)

81. G. Papaefthymiou, K. Dragoon, Towards $100 \%$ renewable energy systems: uncapping power system flexibility, Energy Policy 92, 69-82 (2016)

82. B. Kroposki, Integrating high levels of variable renewable energy into electric power systems, J. Mod. Power Syst. Clean Energy 5, 831-837 (2017)

Cite this article as: Georgia Sarma, Anastasia Zabaniotou, Understanding Vulnerabilities of Renewable Energy Systems For Building Their Resilience to Climate Change Hazards: Key Concepts And Assessment Approaches, Renew. Energy Environ. Sustain. 6, 35 (2021) 